\title{
Author Correction: Multiperiod Multi Traveling Salesmen Problem Considering Time Window Constraints with an Application to a Real World Case
}

\section{Haluk Yapicioglu ${ }^{1}$}

Published online: 29 November 2017

(C) Springer Science+Business Media, LLC, part of Springer Nature 2017

\section{Author Correction: Netw Spat Econ https://doi.org/10.1007/s11067-017-9367-9}

The title of the article, Multiperiod Multi Traveling Salesmen Problem with Time Window Constraints, was changed as shown above.

The original article has been corrected.

The online version of the original article can be found at https://doi.org/10.1007/s11067-017-9367-9

Haluk Yapicioglu

hyapicio@anadolu.edu.tr

1 Department of Industrial Engineering, Anadolu University, 26555 Eskisehir, Turkey 